\title{
Prevalence of anaemia and its associated factors in African children at one and three years residing in the Capricorn District of Limpopo Province, South Africa
}

\begin{tabular}{|c|c|}
\hline \multicolumn{2}{|c|}{$\begin{array}{l}\text { Authors: } \\
\text { Ramoteme L. Mamabolo }{ }^{1} \\
\text { Marianne Alberts }{ }^{2}\end{array}$} \\
\hline \multicolumn{2}{|c|}{$\begin{array}{l}\text { Affiliations: } \\
{ }^{1} \text { School of Health Sciences, } \\
\text { Department of Nutrition, } \\
\text { University of Venda, } \\
\text { Thohoyandou, South Africa }\end{array}$} \\
\hline \multicolumn{2}{|c|}{$\begin{array}{l}{ }^{2} \text { Medical Sciences } \\
\text { Programme, University of } \\
\text { Limpopo, Turfloop Campus, } \\
\text { Polokwane, South Africa }\end{array}$} \\
\hline \multicolumn{2}{|c|}{$\begin{array}{l}\text { Correspondence to: } \\
\text { Ramoteme Mamabolo }\end{array}$} \\
\hline \multicolumn{2}{|c|}{$\begin{array}{l}\text { Email: } \\
\text { ramoteme.mamabolo@ } \\
\text { univen.ac.za }\end{array}$} \\
\hline \multicolumn{2}{|c|}{$\begin{array}{l}\text { Postal address: } \\
\text { Private Bag X5050, } \\
\text { Thohoyandou 0950, } \\
\text { South Africa }\end{array}$} \\
\hline \multicolumn{2}{|c|}{$\begin{array}{l}\text { Dates: } \\
\text { Received: } 19 \text { Mar. } 2013 \\
\text { Accepted: } 02 \text { Jul. } 2014 \\
\text { Published: } 23 \text { Sept. } 2014\end{array}$} \\
\hline \multicolumn{2}{|c|}{$\begin{array}{l}\text { How to cite this article: } \\
\text { Mamabolo, R.L. \& Alberts, } \\
\text { M., 2013, 'Prevalence of } \\
\text { anaemia and its associated } \\
\text { factors in African children } \\
\text { at one and three years } \\
\text { residing in the Capricorn } \\
\text { District of Limpopo Province, } \\
\text { South Africa', Curationis } \\
\text { 37(1), Art. \#1160, } 9 \text { pages. } \\
\text { http://dx.doi.org/10.4102/ } \\
\text { curationis.v37i1.1160 }\end{array}$} \\
\hline \multicolumn{2}{|c|}{$\begin{array}{l}\text { Copyright: } \\
\text { C 2014. The Authors. } \\
\text { Licensee: AOSIS } \\
\text { OpenJournals. This work } \\
\text { is licensed under the } \\
\text { Creative Commons } \\
\text { Attribution License. }\end{array}$} \\
\hline \multicolumn{2}{|l|}{ Read online: } \\
\hline 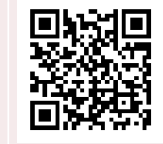 & $\begin{array}{l}\text { Scan this QR } \\
\text { code with your } \\
\text { smart phone or } \\
\text { mobile device } \\
\text { to read online. }\end{array}$ \\
\hline
\end{tabular}

Objective: The present study evaluated the prevalence of anaemia and its determinants in one- and three-year-old children from the Capricorn District of Limpopo Province, South Africa.

Methods: A prospective cohort study conducted in rural villages in the Capricorn District of Limpopo Province, South Africa. At birth, a cohort of 219 children was followed until they were one and three years of age. Data collected included the children's anthropometric measurements, blood for biochemical analysis (full blood count, ferritin, folate and vitamin B12) and socio-demographic status.

Results: At one year, anaemia $(\mathrm{Hb}<11 \mathrm{~g} / \mathrm{dL})$ was present in $52 \%$ of the children, decreasing to $22 \%$ by the third year. Iron deficiency (ferritin $<12 \mu \mathrm{g} / \mathrm{mL}$ ) was common in these children (39\% and 33\% at one year and three years, respectively) particularly in the presence of anaemia. Folate and vitamin B12 deficiencies $(<5 \mathrm{ng} / \mathrm{mL}$ and $<145 \mathrm{pg} / \mathrm{mL}$, respectively) were common at one year, with the children accumulating enough vitamin B12 by three years; however, folate deficiency levels remained fairly constant between the two time points.

Conclusion: There was a high prevalence of anaemia in the study participants at one year and three years of age. Factors that increased the risk of anaemia at three years were: a mother with only a primary school education, anaemia at one year, male gender, overweight, and combined overweight and stunting. Protective factors against anaemia were having a younger mother who served as the main caregiver.

\section{Introduction}

In developing countries, anaemia and iron deficiency are common in women of reproductive age, infants and young children, and it is estimated that $36 \%$ of the world's population suffers from anaemia (UNICEF/WHO 1999). According to the World Health Organization (WHO) database, in industrialised countries, pregnant women $(4 \%-15 \%)$, pre-school children $(12 \%-16 \%)$, nonpregnant women $(12 \%-13 \%)$ and the elderly $(1 \%-2 \%)$ are the groups most commonly affected by anaemia. In African countries and other developing regions, although the same groups are involved, reported frequencies are much greater: pregnant women $(8 \%-22 \%)$, pre-school children $(9 \%-26 \%)$, non-pregnant women $(10 \%-23 \%)$ and the elderly $(0 \%-6 \%)$ (De Benoist et al. 2008). Additionally, anaemia is common amongst pre-school children (42\%), with the highest global rates occurring in Africa (56\%) (United Nations 1991). In 1994, the South African Vitamin A Consultative Group found that, nationally, 21\% of children aged between 6 and 71 months were anaemic $(\mathrm{Hb}<11 \mathrm{~g} / \mathrm{dL})$, and that iron deficiency (ferritin $<12 \mathrm{~g} / \mathrm{dL}$ ) was present in $10 \%$ of these children (Labadarios \& Van MiddelKoop 1995). These high anaemia rates in children have mainly been related to the higher iron requirements of children for rapid growth, and the low content of bioavailable iron in their diets (Hassan et al. 1997; Oski 1993:190).

Iron deficiency has serious long-term consequences for children, such as: increased susceptibility to infections, increased fragility, poor physical growth, decreased appetite, reduced mental performance, retardation of cognitive and psychomotor development, and congestive cardiac failure (Grantham-Mcgregor \& Ani 2001; Haas \& Brownlie 2001).

Factors that lead to iron deficiency anaemia include inadequate bioavailable dietary iron, and poor absorption due to the presence of dietary inhibitors of iron absorption, such as tannin in tea and phytates from plants (Ferguson et al. 1993:1487; Hassan et al. 1997:2194). Earlier studies found that breastfeeding after six months of age without iron supplementation, use of non-iron fortified cow's milk as a weaning food, early and frequent consumption of tea and relatively infrequent consumption of meat contribute to iron deficiency in infants (Hassan et al. 1997:2194; 
Male et al. 2001:492). Anaemia in children is also associated with poorer socio-economic status (Hassan et al. 1997:2194; Oski 1993:190).

Other nutritional anaemias due to deficiencies may also occur in children, such as those of folate and vitamin B12 (Allen et al. 1995:1013; Neumann \& Harrison 1994:S90; Rogers et al. 2003:27). Both folate and vitamin B12 are involved in the aetiology of megaloblastic anaemia, but little is known about their status in young children. The reported studies on vitamin B12 status in children have been limited to children born to vegetarian mothers and it is likely that these children had low vitamin B12 stores (Specker et al. 1988:89; Specker et al. 1990:1073). In a Guatemalan study, a high prevalence of vitamin B12 deficiency (as assessed by urinary methylmalonic acid: creatinine ratio) was found in the infants (Specker et al. 1988:89; Specker et al. 1990:1073). Furthermore, it was found that concentrations of vitamin B12 in maternal breast milk were associated with infant vitamin B12 depletion (Specker et al. 1988:89; Specker et al. 1990:1073).

Limpopo Province (Limpopo) has the highest prevalence of anaemia in pre-school children in South Africa (34.2\%; $C I=28.4 ; 40.1)$ (Labadarios \& Van MiddelKoop 1995), and mothers of these children have a high prevalence of anaemia (16.4\%) during pregnancy (Mamabolo et al. 2004a:15). As a result, the present study was conducted to investigate the determinants of anaemia in these children at one and three years of age. Furthermore, these mothers practiced long durations of breastfeeding, although not exclusively as they tended to introduce supplementary feeds to the children at an early age (Mamabolo et al. 2004b:327). In addition, the children were found to be following a diet that was poor in micronutrients (Mamabolo et al. 2006:102).

\section{Aims of the study}

This study was aimed at examining the levels of iron, serum folate and vitamin B12, and the prevalence of anaemia and its determinants in children at one and three years of age in a typical rural area in the Capricorn region of Limpopo, South Africa.

Objectives:

- To determine the prevalence of anaemia in African children from disadvantaged communities at one and three years of age.

- To determine the prevalence of vitamin B12 and folate deficiencies in African children from disadvantaged communities at one and three years of age.

- To determine the factors that cause anaemia in African children from disadvantaged communities at one and three years of age.

\section{Significance of the study}

Micronutrient deficiencies, especially iron, are known to have long-term consequences for children, which include neurological, cognitive and motor development.
Furthermore, iron deficiency in children increases susceptibility to infections and decreased appetite, amongst others (Grantham-Mcgregor \& Ani 2001:649; Haas \& Brownlie 2001:676S). If severe iron deficiency leads to anaemia, which has also been associated with poor sociodemographic conditions such as maternal education and unemployment, which may result in poor feeding practices, then this poses a significant public health problem from this vulnerable group (Ferguson et al. 1993:1487; Hassan et al 1997:2194). In addition to iron, other causes of anaemia are folate and vitamin B12 deficiencies, which result in megaloblastic anaemia (Neumann \& Harrison 1994:S90; Rogers et al. 2003:27). In view of the fact that Limpopo is one of the poorer provinces in South Africa, and that there is a paucity of data in the province with regards to micronutrient status, the present study adds to the scientific knowledge towards this vulnerable group. The results may also assist health-policy makers in identifying gaps that need to be filled in the area of combating micronutrient deficiencies in the province. This is more so for rural areas where there is a high intake of poor-quality diets containing tannins and phytates, which are known to inhibit iron absorption (Mamabolo et al. 2004b:327; Mamabolo et al. 2006:102).

\section{Research method and design \\ Study area}

The present study was undertaken in villages situated in the Capricorn region of the Limpopo Province, South Africa, which were being serviced by the nine randomly selected clinics at baseline (Mamabolo et al 2004a). The villages in this region are predominately rural with poor infrastructure, lack of electricity and proper sanitation, poor roads, and poorly equipped schools. The villages rely mainly on subsistence farming for a living (Alberts, Burger \& Tollman 1999:851).

\section{Study design}

The present study formed part of a longitudinal quantitative study that aimed at investigating the effects of maternal factors on nutritional status of their children. The study followed infants born to third-trimester-pregnant women who were followed over a period of three years, with measurements (anthropometry, dietary intake and blood) taken at regular intervals (1, 3, 6, 9, 12 and 36 months) (Mamabolo et al. 2004a; 2004b; 2006).

\section{Study population}

Participants were infants born to pregnant women who were recruited whilst attending prenatal clinics at nine randomly selected local clinics situated around the referral hospital (Mankweng) during their third trimester. All of the children who presented themselves during the first year and third year follow-up visit were eligible for the study. Of the 276 women who were recruited into the study, 219 gave birth at Mankweng Hospital and all infants were born at term. The missing subjects were due to the mother migrating out of the study area, home deliveries, or spontaneous miscarriages. 
After birth, the children were visited at one year and three years of age; the present study describes the findings of when these children were aged one year and three years. Of the 219 who gave birth at Mankweng Hospital, 156 were traced and returned for the one-year visit, and 162 returned at three years of age. This change in numbers can be accounted for by migrations within the studied villages as well as emigrations and immigrations resulting in some infants missing some follow-up periods but availing themselves to the next followup. Lack of proper addresses, formal streets and roads in these villages complicated the process of tracing mothers and their children.

\section{Data collection method}

\section{Anthropometric measurements}

Anthropometric measurements of the children at one year and three years of age were taken. Weight was determined with a baby scale (TANITA Baby Scale, Model 1380, Tanita Corporation, Tokyo, Japan), with the baby naked, to the nearest $0.1 \mathrm{~kg}$. The baby scale was calibrated using a beam balance. At one year, length was measured with a nonstretchable tape measure mounted on a board to the nearest $0.5 \mathrm{~cm}$, with the baby lying down. At 3 years, height was measured; this was performed with the child standing on a flat surface against the wall with the head in the Frankfort position (Mamabolo et al 2004b:327; 2006).

\section{Blood collection and analysis}

Trained phlebotomists collected fasting blood samples after application of a local anaesthaetic ointment to minimise pain in the children. The blood was used to determine haemoglobin $(\mathrm{Hb})$ and red cell indices using a Coulter STKS analyser (Beckman Coulter Inc., California, USA). Ferritin, vitamin B12 and serum folate levels were determined by the Access ImmunoAssay autoanalyzer ${ }^{\circledR}$ (Beckman Coulter Inc., California, USA). C-reactive protein was determined using the Dimension SMS autoanalyzer ${ }^{\circledR}$ (Beckman Coulter Inc., California, USA). Reference ranges for biochemical values were taken as Haemoglobin $(<11 \mathrm{~g} / \mathrm{dL})$; Haematocrit (<33\%); $\mathrm{MCV}(<72 \mathrm{fl}) ; \mathrm{MCH}(<24 \mathrm{pg})$; ferritin $(<12 \mu \mathrm{g} / \mathrm{mL})$; serum folate $(<5 \mathrm{ng} / \mathrm{mL})$ and Vitamin B12 $(<145 \mathrm{pg} / \mathrm{mL})$ (WHO/CDC 2008; WHO 2012). Results on folate deficiency have to be cautiously interpreted as they reflect deficiencies as assessed by serum levels, which are known to be affected by short-term dietary intakes of folate, and not by red cell folate levels, which are better at assessing long-term status.

\section{Data analysis}

Statistical analyses were performed using SPSS 20.0 for Windows (SPSS Inc., Chicago, USA). Skewed data were $\log$ transformed to approximate normality before analysis (SPSS Inc., Chicago, USA, 2013). Data are presented as means \pm s.d., proportions and odds ratios $(95 \%$ CI). Statistical tests included descriptive statistics, frequencies, Pearson's correlations and cross tabulations (Armitage, Berry \& Matthews 2002). Continuous data were compared using
Student's $t$-test and categorical data using chi-squared test. Binary logistic regressions were done to assess associations between basic anthropometric and socio-demographic variables and anaemic status (Armitage et al. 2002).

\section{Ethical approval}

Ethical approval and permission to undertake the study were obtained from the University of Limpopo (Turfloop Campus) Ethics Committee (Ethics number: EC99/345) and the Limpopo Province Department of Health and Welfare's Research Committee. Informed consent for participation of the children in the study was obtained from their mothers and or caregivers prior to any measurements being taken.

\section{Results}

\section{At one year of age}

Baseline maternal characteristics and birth anthropometry did not differ between the group of children who reported for the one-year visits and those who did not. Blood samples were obtained from 127 of the 156 children. Anaemia, defined by WHO as $\mathrm{Hb}$ levels $<11 \mathrm{~g} / \mathrm{dL}$, was found in 66 of the children $(52 \%)$. Of these, four $(3.0 \%)$ had severe $(\mathrm{Hb}<7$ $\mathrm{g} / \mathrm{dL}), 54(42.4 \%)$ had moderate ( $\mathrm{Hb} 7.7-9.9 \mathrm{~g} / \mathrm{dL})$, and 69 (54.6\%) had mild anaemia ( $\mathrm{Hb} 10.1-10.9 \mathrm{~g} / \mathrm{dL})$. Subsequent comparisons were based upon the presence of anaemia $(\mathrm{Hb}$ $<11 \mathrm{~g} / \mathrm{dL})$ and its absence $(\mathrm{Hb}>11 \mathrm{~g} / \mathrm{dL})$.

There were no differences in the anthropometric measurements at one year between the two groups; however, as seen in Table 1, the anaemic children had significantly lower levels of haemoglobin, ferritin, haematocrit, MCV and $\mathrm{MCH}$. Mean serum folate and vitamin B12 levels did not differ between the groups.

In the total group, 50 children (39.4\%) had iron deficiency (ferritin levels < $12 \mu \mathrm{g} / \mathrm{mL}), 13(10.2 \%)$ had vitamin B12 $(<145 \mathrm{pg} / \mathrm{mL})$ and $29(22.8 \%)$ had serum folate $(<5 \mathrm{ng} / \mathrm{mL})$ deficiencies (Table 2$)$. In those children with anaemia, $33(50.0 \%)$ had iron deficiency, 9 (13.6\%) had vitamin B12 deficiency and 16 (24.2\%) had folate deficiency. Furthermore, of the anaemic children, three (4.5\%) had combined iron and vitamin B12 deficiencies, and two (3.0\%) had combined iron, vitamin B12 and serum folate deficiencies. Combined iron and serum folate deficiencies were noted in eight children $(12.1 \%)$ in this group, whilst two $(3.0 \%)$ had combined vitamin B12 and serum folate deficiencies (data not shown). These findings suggest that iron deficiency alone could be accounting for $22(33.3 \%)$ of the anaemic cases.

Vitamin B12 and combined iron and vitamin B12 deficiencies could account for three $(4.5 \%)$ cases each, serum folate deficiency for four $(6.0 \%)$, combined iron and serum folate deficiency for two (3.0\%) and combined serum folate and vitamin B12 deficiencies for eight (12.1\%) of the anaemic cases (data not shown). Thus, overall, the measured micronutrients may have accounted for $42(63.4 \%)$ of the anaemic cases seen in this group of children. There were no gender differences 
between the children with respect to their biochemical and anthropometric measurements.

\section{At three years of age}

Blood samples were collected from 143 (88.3\%) of the 162 children who attended this visit (Table 3 ). The only gender difference observed at three years was in body weight, with male children $(14.19 \pm 2.01 \mathrm{~kg})$ being heavier than female children $(13.51 \mathrm{~kg} \pm 1.94 \mathrm{~kg}), p=0.032$.

At three years, anaemia was present in $22.0 \%$ of the children compared with $52.0 \%$ two years earlier (Table 4 ). The anaemia was moderate in $10(32.3 \%)$ and mild in 21 (67.7\%) children. None of the children had severe anaemia. Anthropometric measurements and vitamin levels of the two groups (anaemic and non-anaemic) did not differ.

Iron deficiency was more common in the anaemic group. The proportion with iron deficiency increased from 50.0\% at one year in the anaemic group to $63.0 \%$ at three years. No children were found to be vitamin B12 deficient at three years. At this age, there were also no significant differences in nutritional status (stunting, underweight and obesity) between the two groups.

In the anaemic children, folate deficiency was present in eight $(26.0 \%)$ children, iron deficiency in $20(63.0 \%)$ and combined folate and iron deficiency was present in three $(10.0 \%)$ children.

Factors associated with anaemia at three years were examined by bivariate logistic regression (Table 5). The risk of anaemia was increased: 20 times when the mother had only a primary school education; 6 times for male children; 17 times if the child was anaemic at one year; 13 times if the child was overweight; and 20 times if the child was both overweight and stunted. On the other hand, having a mother as the primary caregiver or a mother aged below 20 years were protective factors.

\section{Discussion}

The major findings in the present study were that there was a high prevalence of anaemia and iron deficiency, and to a lesser degree, folate deficiency, whereas vitamin B12 deficiency was less prevalent. The high prevalence of anaemia and iron deficiency in the present study is in agreement with studies conducted in developing countries, including South Africa (Table 6).

Some of the South African studies have used lower cut-off values for ferritin $(<10 \mu \mathrm{g} / \mathrm{mL})$, which could have resulted in the differences seen in the prevalence of iron deficiency. This makes the large range $(17 \%-83 \%)$ in prevalence of anaemia, particularly in younger children ( $<36$ months), more

TABLE 1: Descriptive statistics (mean \pm s.d.) of children's hematological, biochemical and anthropometric measurements at one year of age.

\begin{tabular}{|c|c|c|c|c|}
\hline Variables & $\begin{array}{l}\text { Total } \\
(n=127)\end{array}$ & $\begin{array}{l}\text { Anaemic } \\
(\mathrm{Hb}<11 \mathrm{~g} / \mathrm{dL}) \\
(n=66)\end{array}$ & $\begin{array}{l}\text { Non-anaemic } \\
(\mathrm{Hb}>11 \mathrm{~g} / \mathrm{dL}) \\
(n=61)\end{array}$ & $\begin{array}{l}p \text {-value } \\
(t \text {-test) }\end{array}$ \\
\hline Haemoglovbin (g/dL) & $10.71 \pm 1.36$ & $9.72 \pm 1.10$ & $11.77 \pm 0.62$ & 0.0001 \\
\hline Haematocrit (\%) & $33.63 \pm 3.57$ & $31.66 \pm 3.24$ & $35.76 \pm 2.55$ & $<0.0001$ \\
\hline $\mathrm{MCH}$ & $23.54 \pm 3.03$ & $21.81 \pm 2.87$ & $25.41 \pm 1.86$ & $<0.0001$ \\
\hline MCV & $73.41 \pm 26.94$ & $70.11 \pm 6.90$ & $76.99 \pm 4.96$ & $<0.0001$ \\
\hline Vitamin B12 (pg/mL) & $362.42 \pm 219.37$ & $331.85 \pm 193.92$ & $395.48 \pm 241.20$ & 0.091 \\
\hline Birth weight (kg) & $3.11 \pm 0.53$ & $3.07 \pm 0.49$ & $3.16 \pm 0.57$ & 0.323 \\
\hline Weight at 1 year (kg) & $9.35 \pm 1.41$ & $9.39 \pm 1.46$ & $9.30 \pm 1.37$ & 0.726 \\
\hline Weight gain 0-1 year & $6.34 \pm 1.28$ & $6.43 \pm 1.28$ & $6.24 \pm 1.29$ & 0.428 \\
\hline HAZ & $-1.36 \pm 1.36$ & $-1.27 \pm 1.25$ & $-1.45 \pm 1.48$ & 0.454 \\
\hline WAZ & $-0.67 \pm 1.24$ & $-0.67 \pm 1.31$ & $-0.67 \pm 1.17$ & 0.998 \\
\hline WHZ & $0.40 \pm 1.36$ & $0.31 \pm 1.25$ & $0.51 \pm 1.47$ & 0.418 \\
\hline
\end{tabular}

HAZ, height-for-age $z$-score; WAZ, weight-for-age z-score; WHZ, weight-for-height z-score.

TABLE 2: Percentage of children below the reference ranges of hematological, biochemical and anthropometric measurements at one year of age.

\begin{tabular}{|c|c|c|c|c|c|}
\hline \multirow[t]{2}{*}{ Variables } & \multirow[t]{2}{*}{$\begin{array}{l}\text { Reference } \\
\text { ranges }\end{array}$} & \multirow{2}{*}{$\begin{array}{c}\text { Total }(n=127) \\
N(\%)\end{array}$} & \multirow{2}{*}{$\begin{array}{c}\begin{array}{c}\text { Anaemic } \\
(\mathrm{Hb}<11 \mathrm{~g} / \mathrm{dL})(n=66)\end{array} \\
N(\%)\end{array}$} & \multirow{2}{*}{$\begin{array}{c}\begin{array}{c}\text { Non-anaemic } \\
(\mathrm{Hb}>11 \mathrm{~g} / \mathrm{dL})(n=61)\end{array} \\
N(\%)\end{array}$} & \multirow[t]{2}{*}{$p$-value } \\
\hline & & & & & \\
\hline Haemoglobin (g/dL) & $<11 \mathrm{~g} / \mathrm{dL}$ & $66(52.0)$ & - & - & - \\
\hline Haematocrit (\%) & $<33 \%$ & $52(40.9)$ & $48(72.7)$ & $4(6.6)$ & $<0.0001$ \\
\hline $\operatorname{MCV}(f l)$ & $<72 \mathrm{fl}$ & $47(37.0)$ & $35(53.0)$ & $12(19.7)$ & $<0.0001$ \\
\hline $\mathrm{MCH}(\mathrm{pg})$ & $<24 \mathrm{pg}$ & $63(49.6)$ & $48(72.7)$ & $15(24.6)$ & $<0.0001$ \\
\hline Ferritin $(\mu \mathrm{g} / \mathrm{mL})$ & $<12 \mu \mathrm{g} / \mathrm{mL}$ & $50(39.4)$ & $33(50.0)$ & $17(27.9)$ & 0.012 \\
\hline Serum folate $(\mathrm{ng} / \mathrm{mL})$ & $<5 \mathrm{ng} / \mathrm{mL}$ & $29(22.8)$ & $16(24.2)$ & $13(21.3)$ & 0.427 \\
\hline Vitamin B12 (pg/mL) & $<145 \mathrm{pg} / \mathrm{mL}$ & $13(10.2)$ & $9(13.6)$ & $4(6.6)$ & 0.246 \\
\hline $\mathrm{HAZ}$ & $<-2$ s.d. & $42(33.1)$ & $22(33.3)$ & $20(32.8)$ & 0.623 \\
\hline WAZ & $<-2$ s.d. & $14(11.0)$ & $7(10.6)$ & $7(11.5)$ & 0.868 \\
\hline WHZ & $>2$ s.d. & $15(11.8)$ & $7(10.6)$ & $8(13.1)$ & 0.481 \\
\hline
\end{tabular}

HAZ, height-for-age $z$-score; WAZ, weight-for-age z-score; WHZ, weight-for-height z-score. 
difficult to explain. A few reasons could have accounted for these differences. First, it should be remembered that South Africa is a country that has large inequities, particularly in terms of socio-economic variables. Second, there are large disparities between urban and rural areas, particularly with regard to health facilities. Third, some of the geographical areas have higher rates of infectious diseases (such as malaria) and parasite infestations, which further contribute to the burden of anaemia (Lartey et al. 2000:199; Muhe et al. 2000:805; Stoltzfus et al. 2000:1724). A study conducted by Malope et al. (2001:84), however, revealed that worm infestations were uncommon in children aged 8-72 months residing in the area, which ruled out increased worm load as a contributing factor to this problem.

The percentage of anaemic children decreases when taking older children (> 24 months) into consideration (Table 6), which is also a trend observed in the present study, where, by three years of age, superficially, the prevalence of anaemia was reduced by half from that at one year. This pattern of decreasing prevalence of anaemia with age has also been reported by others (Adish et al. 1999:243; Stoltzfus et al 2000:1724). This was not the case with iron deficiency, which remained similar at both one year and three years.

The prevalence of anaemia and iron deficiency in this and other studies from developing countries were obtained by using the WHO criteria $(\mathrm{Hb}<11 \mathrm{~g} / \mathrm{dL})$. The investigators of the Avon Longitudinal Survey of Pregnancy and Childhood (ALSPAC) in the United Kingdom (Emond et al. 1996:36; Sherriff et al. 1999:153) questioned the appropriateness of the WHO criteria for anaemia $(\mathrm{Hb}<11 \mathrm{~g} / \mathrm{dL})$ and iron deficiency $(<12 \mu \mathrm{g} / \mathrm{mL})$ in one-year-old children. This was based on their observations that there were no major changes in haemoglobin levels in infancy, whereas ferritin levels changed with increasing age of the children. They suggested that the cut-off level for haemoglobin be lowered to $10 \mathrm{~g} / \mathrm{dL}$ and that the level for iron deficiency be raised to ferritin $<16 \mu \mathrm{g} / \mathrm{mL}$. Using this criterion in the present study, the prevalence of anaemia was found to have dropped to $23.6 \%$ and the iron deficiency increased to $52.8 \%$ at one year of age. Furthermore, it is well documented that in children and adults, Africans present with lower haemoglobin levels than their white counterparts, as such, this could result in an overestimation of the anaemic status of the children in the present study.

In addition, it is known that physiologically the level of haemoglobin increases with age in all population groups. This could have in itself resulted in the halving of the incidence of anaemia between the ages of one and three years. This could serve as an indication of the importance of early intervention in combating the problem before normal physiological processes mask its early deleterious effects.

TABLE 3: Descriptive statistics (mean \pm s.d.) of children's hematological, biochemical and anthropometric measurements at three years of age.

\begin{tabular}{|c|c|c|c|c|}
\hline Variables & $\begin{array}{l}\text { Total } \\
(n=143)\end{array}$ & $\begin{array}{l}\text { Anaemic } \\
(\mathrm{Hb}<11 \mathrm{~g} / \mathrm{dL}) \\
(n=31)\end{array}$ & $\begin{array}{l}\text { Non-Anaemic } \\
(\mathrm{Hb}>11 \mathrm{~g} / \mathrm{dL}) \\
(n=112)\end{array}$ & $p$-value \\
\hline Haemoglobin $(\mathrm{g} / \mathrm{dL})$ & $11.85 \pm 1.16$ & $10.11 \pm 0.67$ & $12.31 \pm 0.77$ & 0.0001 \\
\hline Ferritin $(\mu \mathrm{g} / \mathrm{mL})$ & $20.76 \pm 14.12$ & $13.72 \pm 11.91$ & $22.33 \pm 14.29$ & 0.004 \\
\hline Haematocrit (\%) & $34.99 \pm 3.26$ & $30.95 \pm 3.03$ & $36.05 \pm 2.38$ & $<0.0001$ \\
\hline $\mathrm{MCH}$ & $26.65 \pm 2.45$ & $24.28 \pm 2.94$ & $27.27 \pm 1.88$ & $<0.0001$ \\
\hline $\mathrm{MCV}$ & $77.98 \pm 5.91$ & $72.22 \pm 6.97$ & $79.48 \pm 4.56$ & $<0.0001$ \\
\hline Vitamin B12 (pg/mL) & $448.73 \pm 206.38$ & $468.00 \pm 195.02$ & $448.99 \pm 211.02$ & 0.523 \\
\hline C-reactive protein & $3.26 \pm 10.06$ & $2.01 \pm 3.25$ & $3.56 \pm 11.24$ & 0.681 \\
\hline Weight at 3-years (kg) & $13.87 \pm 1.99$ & $14.25 \pm 2.16$ & $13.76 \pm 1.95$ & 0.216 \\
\hline HAZ & $-1.97 \pm 1.05$ & $-1.94 \pm 1.04$ & $-1.98 \pm 1.06$ & 0.848 \\
\hline WAZ & $-0.49 \pm 1.16$ & $-0.25 \pm 1.19$ & $-0.55 \pm-.15$ & 0.207 \\
\hline WHZ & $0.89 \pm 1.25$ & $1.13 \pm 1.18$ & $0.82 \pm 1.27$ & 0.224 \\
\hline BMI $\left(\mathrm{kg} / \mathrm{m}^{2}\right)$ & $18.07 \pm 2.30$ & $18.49 \pm 2.24$ & $17.96 \pm 2.31$ & 0.250 \\
\hline
\end{tabular}

HAZ, height-for-age $z$-score; WAZ, weight-for-age $z$-score; WHZ, weight-for-height $z$-score; BMI, body mass index.

TABLE 4: Percentage of children below reference ranges of the hematological, biochemical and anthropometric measurements at three years of age.

\begin{tabular}{|c|c|c|c|c|c|}
\hline \multirow[t]{2}{*}{ Variables } & \multirow[t]{2}{*}{$\begin{array}{l}\text { Reference } \\
\text { ranges }\end{array}$} & Total $(n=143)$ & \multirow{2}{*}{$\begin{array}{c}\begin{array}{c}\text { Anaemic } \\
(\mathrm{Hb}<11 \mathrm{~g} / \mathrm{dL}) \\
(n=31)\end{array} \\
N(\%)\end{array}$} & \multirow{2}{*}{$\begin{array}{c}\begin{array}{c}\text { Non-anaemic }(\mathrm{Hb}>11 \mathrm{~g} / \mathrm{dL}) \\
(n=112)\end{array} \\
N(\%)\end{array}$} & \multirow[t]{2}{*}{$p$-value } \\
\hline & & $N(\%)$ & & & \\
\hline Haemoglobin (g/dL) & $<11 \mathrm{~g} / \mathrm{dL}$ & $31(21.7)$ & - & - & - \\
\hline Haematocrit (\%) & $<33 \%$ & $34(24.0)$ & $23(74.2)$ & $12(10.9)$ & $<0.0001$ \\
\hline $\mathrm{MCV}(\mathrm{fl})$ & $<72 \mathrm{fl}$ & $21(14.7)$ & $18(58.1)$ & $4(3.4)$ & $<0.0001$ \\
\hline $\mathrm{MCH}(\mathrm{pg})$ & $<24 \mathrm{pg}$ & $17(12.0)$ & $15(48.4)$ & $3(2.5)$ & $<0.0001$ \\
\hline Ferritin $(\mu \mathrm{g} / \mathrm{mL})$ & $<12 \mu \mathrm{g} / \mathrm{mL}$ & 47 (32.9) & $20(63.0)$ & $30(26.8)$ & 0.001 \\
\hline Serum folate $(\mathrm{ng} / \mathrm{mL})$ & $<5 \mathrm{ng} / \mathrm{mL}$ & $28919.6)$ & $8(25.9)$ & $20(17.9)$ & 0.243 \\
\hline Vitamin B12 (pg/mL) & $<145 \mathrm{pg} / \mathrm{mL}$ & $0(0.0)$ & $0(0.0)$ & $0(0.0)$ & - \\
\hline $\mathrm{HAZ}$ & $<-2$ s.d. & $69(46.3)$ & $15(48.4)$ & $51(45.8)$ & 0.476 \\
\hline WAZ & $<-2$ s.d. & $9(8.7)$ & $3(6.5)$ & $10(9.3)$ & 0.851 \\
\hline WHZ & $>2$ s.d. & $28(17.4)$ & $6(19)$. & 19 (16.9) & 0.839 \\
\hline BMI & obese & $38(24.2)$ & $9(29.0)$ & 26 (22.9) & 0.376 \\
\hline
\end{tabular}

HAZ, height-for-age z-score; WAZ, weight-for-age z-score; WHZ, weight-for-height z-score; BMI, body mass index. 
TABLE 5: Bivariate analysis of association of risk factors with anaemia in the children at three years of age.

\begin{tabular}{|c|c|c|c|}
\hline $\begin{array}{l}\text { Risk factor } \\
\text { (Reference category) }\end{array}$ & $\%$ Non-anaemic & $\%$ Anaemic & or $(95 \% \mathrm{Cl})$ \\
\hline \multicolumn{4}{|l|}{ Maternal Age (years) } \\
\hline Less than 20 years & 28.0 & 9.7 & $0.015(0.00-0.27)$ \\
\hline Above 30 years & 28.0 & 25.8 & $0.150(0.02-1.92)$ \\
\hline $20-30$ years & 44.0 & 64.5 & - \\
\hline \multicolumn{4}{|l|}{ Maternal education } \\
\hline Primary & 11.0 & 12.9 & $20.18(1.65-62.69)$ \\
\hline Secondary & 89.0 & 87.1 & - \\
\hline \multicolumn{4}{|l|}{ Maternal Occupation } \\
\hline Working & 16.1 & 25.8 & $0.99(0.07-14.54)$ \\
\hline Student & 13.6 & 9.7 & $4.92(0.30-8.87)$ \\
\hline Unemployed & 70.3 & 64.5 & - \\
\hline \multicolumn{4}{|l|}{ House Type } \\
\hline Brick & 72.0 & 80.6 & $3.18(0.51-19.73)$ \\
\hline Other & 28.0 & 19.4 & - \\
\hline \multicolumn{4}{|l|}{ Electricity } \\
\hline No & 70.3 & 77.4 & $1.22(0.21-7.18)$ \\
\hline Yes & 29.7 & 22.6 & - \\
\hline \multicolumn{4}{|l|}{ Child's gender } \\
\hline Male & 47.5 & 51.6 & $5.85(1.90-17.98)$ \\
\hline Female & 52.5 & 48.4 & - \\
\hline \multicolumn{4}{|c|}{ Number of children $<5$ years } \\
\hline Three and more & 18.6 & 19.4 & $0.17(0.01-1.92)$ \\
\hline Less than three & 81.4 & 80.6 & - \\
\hline \multicolumn{4}{|l|}{ Sibling } \\
\hline No & 78.0 & 80.6 & $0.27(0.03-2.24)$ \\
\hline Yes & 22.0 & 19.4 & - \\
\hline \multicolumn{4}{|l|}{ Caregiver } \\
\hline Mother & 76.3 & 61.3 & $0.18(0.03-0.81)$ \\
\hline Other & 23.7 & 19.4 & - \\
\hline \multicolumn{4}{|l|}{ Nutritional status } \\
\hline Stunted & 28.8 & 22.6 & $5.74(0.58-17.67)$ \\
\hline Overweight & 27.1 & 32.3 & $12.84(1.79-20.84)$ \\
\hline Stunted and overweight & 16.9 & 25.8 & $19.85(1.22-32.41)$ \\
\hline Normal & 27.1 & 19.4 & - \\
\hline \multicolumn{4}{|l|}{ Anaemic at 1 year } \\
\hline Anaemic & 44.3 & 78.9 & $16.71(2.22-25.63)$ \\
\hline Normal & 55.7 & 21.1 & - \\
\hline
\end{tabular}

Although ferritin is widely used as a marker for iron status, its value may be limited by its role as an acute-phase reactant, and as such it is known to be elevated in both infections and inflammations; in addition, the other factor to consider is its cost, particularly in developing countries. Thus, whether the mean corpuscular volume $(\mathrm{MCV})$ can be used to estimate the prevalence of normocytic, microcytic and macrocytic anaemias in a population was examined. In populations where other hypochromic anaemias such as thalassaemia are rare, a decreased $\mathrm{MCV}$ is commonly used to indicate iron deficiency. In the present study, the prevalence of microcytosis $(\mathrm{MCV}<72 \mathrm{fl})$, which is another marker of iron deficiency, was close to that revealed by ferritin levels as a marker of iron deficiency in both the total study population and in the anaemic children. In the non-anaemic children, however, the levels revealed by low MCV were lower than those shown by low ferritin levels. The data in the present study suggest that the presence of microcytosis would only be helpful when anaemia is present. The reference ranges used in children vary amongst authors (Bogen et al. 2000:1254; Malope et al. 2001:84), as such complicating the comparison and verification of the usefulness of this tool in diagnosing iron deficiency.

There was a high proportion of children with iron deficiency at one year of age and this was also accompanied by low dietary intake of the children and their mothers' blood iron levels during pregnancy (Mamabolo et al. 2004a; 2004b; 2006). It has been found that children born at term to mothers with adequate iron stores have sufficient iron stores for approximately four months of postnatal growth (Oski 1993:190) and that exclusive breastfeeding for approximately six months is protective against iron deficiency. In this region of Limpopo, studies have shown that at 4-6 months, when infants' body iron stores are exhausted, exclusive breastfeeding is not practiced and mothers of these children were iron deficient in pregnancy $(16.4 \%)$. Furthermore, the mothers tended to introduce complementary foods at

TABLE 6: Prevalence of anaemia and iron deficiency in children from Africa and other developing countries.

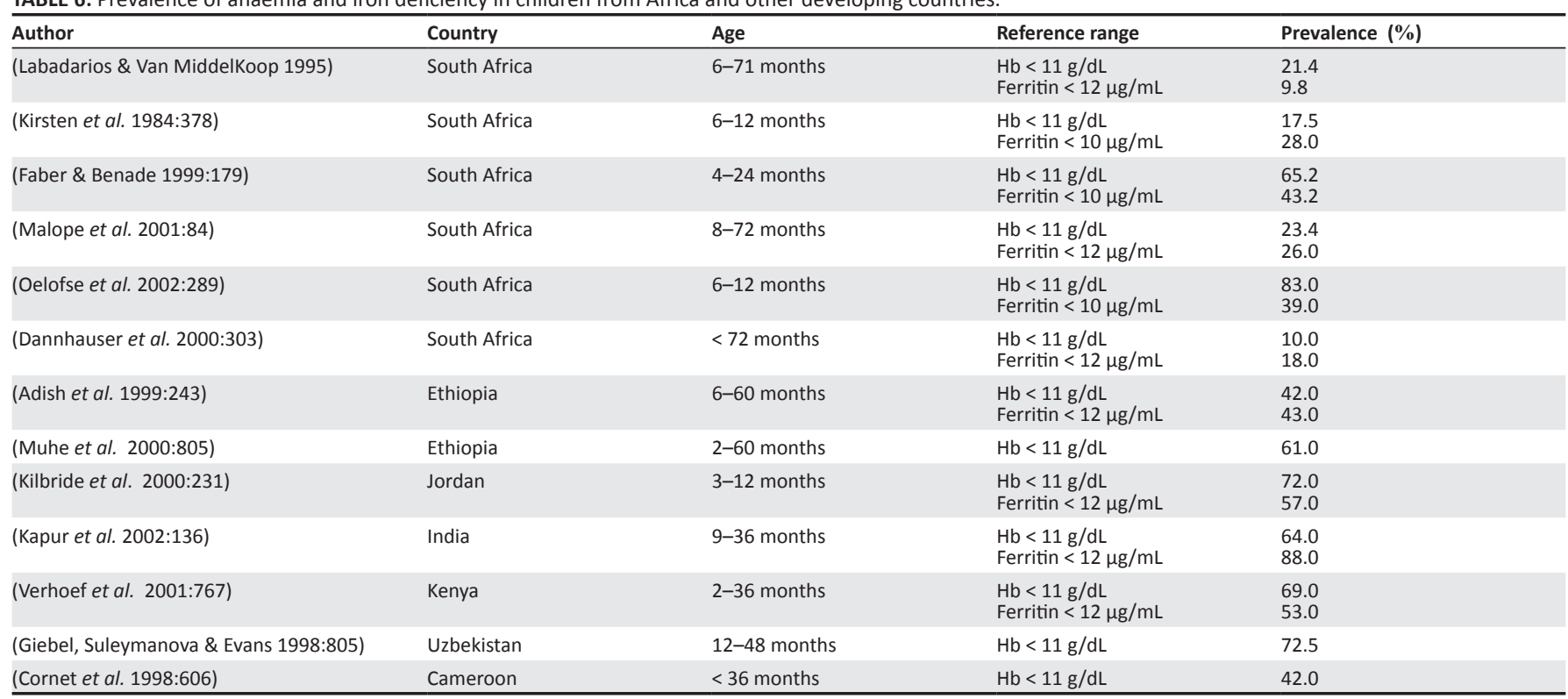


an early age that were not rich in iron (as early as the first week of life). Lactating mothers themselves also consumed a diet that was poor in iron, particularly haem iron, which consisted mainly of maize and starchy vegetables with few animal products (Ladzani, Steyn \& Nel 1998:630; Mostert 2000; Steyn et al. 1993:10). In addition, this diet was high in tannins (tea), low in vitamin C (raw fruit) and high in phytates (green indigenous vegetables), which decrease the bioavailability of the iron (Steyn et al. 1993:10) and are likely to decrease the absorption of the non-haem iron available in food (Oski 1993:190).

Iron deficiency and anaemia have been associated with inadequate environmental conditions, constrained maternal caring capacity, food insecurity and poverty (Adish et al. 1999:243; Schellenberg et al. 2003:581). Previous research (Adish et al. 1999:243) has also shown that women need to protect their own health and nutritional status in order to be effective caregivers. Thus, their levels of education, knowledge of nutrition and employment status determine in part whether they will have the understanding and time to care for their children. In the present study, children of mothers with only primary school education were at increased risk of developing anaemia compared to those of mothers with secondary education and higher. Education may therefore enhance a mother's ability to protect her child from unfavourable conditions and her ability to provide an appropriate diet.

Although disease history prior to collection was not available, it is well known that this can affect childrens' appetites and reduce iron intake. Children in the present study exhibited various states of malnutrition at three years. Anaemia was found to be associated with being stunted (as measured by height-for-age $z$-score) and overweight, as well as being overweight alone. The association of anaemia with stunting is easy to understand since the children generally had a poor diet (energy deficit and deficient micronutrients) over a long period of time, resulting in a deprivation in iron stores. The association with being overweight is more difficult to explain, but it does indicate that having an energy surplus does not necessarily ensure an improved intake of iron. Hence, the children may have had sufficient quantity (kilojoules) but insufficient quality (micronutrients).

The observation of a higher risk of anaemia in male children supports previous reports that have reported a gender difference in iron status in childhood (Lartey et al. 2000:199; Thane et al. 2000:433; Wharf et al. 1997:504), which has been attributed to possibly reflecting the different growth rate between boys and girls. The finding that being anaemic at one year poses a risk of anaemia for children at three years shows that upon depleting their iron stores in early infancy the children have little capacity to accumulate sufficient stores over the next two years. This in itself poses a problem for these children, as this early period is critical in their growth and development in general. Earlier studies have reported gender differences in ferritin levels, with higher levels in girls, which were not confirmed in the present study. There was, however, a significant correlation between ferritin and haemoglobin levels $(r=0.229, p=0.009)$, a finding that has been well documented as both ferritin and haemoglobin levels are known to reflect the body's iron stores (Lawson, Thomas \& Hardiman 1998:420).

Both vitamin B12 and serum folate deficiencies were common in the study in children at one year of age, which may be due to their dietary deficiencies. This is supported by previous data from Limpopo by Steyn et al. (1992:24) and Steyn et al. (2001:143), where a large percentage of pre-school children were found to have folate and vitamin B12 intakes below the Recommended Dietary Allowance (RDA). In women, the mean folate intake was considerably below the RDA, whilst vitamin B12 intake was just marginally adequate. Thus, it is likely that the infants did not receive sufficient vitamin B12 in utero and those who were breastfed during the first year of life (more than $80 \%$ were still breast feeding at nine months) (Mamabolo et al. 2004b:327), may have received inadequate supplies from their mother's milk. This is supported by findings of a study performed by Mostert (2000), in the same area, where it was found that maternal intakes of vitamin B12 and folate were below the RDA levels in lactating mothers (76.1\% and $97.8 \%$ of women, respectively). It was also noted that although folate deficiency remained fairly constant in these children over time, at three years of age there were no cases of vitamin B12 deficiency. This can most probably be explained by the fact that although the diet is largely maize-based, internal organs (i.e. liver, kidneys) are popular sources of meat, from a cultural and economic perspective. The latter are very high in vitamin B12, which is stored over short periods of time in the liver. Additionally, it is likely that at three years these children may be having a more-varied diet with richer sources of vitamin B12 than at one year.

\section{Conclusion}

In conclusion, the study showed a high prevalence of anaemia, iron and serum folate deficiencies in children at both one year and three years of age, albeit lower at the older age. Both anaemia and iron deficiency at one year seem to be associated with low levels in utero followed by rapid growth, mainly in terms of weight gain, which in itself requires more iron to be mobilised. At three years, however, anaemia and iron deficiency seem to be related more to diet and the child's surrounding environment.

\section{Recommendations}

Since anaemia does not present with clear symptoms, and in most cases is asymptomatic, it is difficult to recognise both at home and at the healthcare centers (Schellenberg et al. 2003:581). Hence, it is important that preventative measures rather than curative ones be emphasised. To improve the status of these micronutrients (iron, folate and vitamin B12) in this and similar communities it is recommended that measures be taken: (1) to promote exclusive breastfeeding; (2) to promote proper weaning practices; and (3) to teach mothers about good sources of haem iron and how to 
maximise iron absorption from the diet for their own benefit and that of their children. It remains to be seen whether the introduction of mandatory fortification of maize and wheat flour in 2003 (National Food Fortification Task Group 2002; National Food Fortification Task Group 1998) will impact on the haematological status of South African children, since iron is one of the fortifications that have been added.

\section{Acknowledgements}

This study was supported by grants from the Institute for Research in Extramural Medicine (EMGO), Vrije University, Amsterdam (The Netherlands). We would like to thank Ms A.M. Makwela and Mr R.P. Mamabolo (field workers), and also the nursing staff at the nine clinics for their assistance in conducting this study. We are also grateful to Ms M.H. Mamabolo for her assistance during blood collection.

\section{Competing interests}

The authors declare that they have no financial or personal relationship(s) that may have inappropriately influenced them in writing this article.

\section{Authors' contributions}

R.L.M. (University of Venda) was responsible for the conceptualization of the study, data collection, Laboratory analysis, data analysis and manuscript preparation, whilst M.A. (University of Limpopo, Turfloop Campus) was responsible for the conceptualisation of the study and manuscript preparation.

\section{References}

Adish, A.A., Esrey, S.A., Gyorkos, T.W. \& Johns, T., 1999, 'Risk factors for iron deficiency anaemia in preschool children in northern Ethiopia', Public Health Nutrition 2(3), 243-252. http://dx.doi.org/10.1017/S1368980099000336

Alberts, M., Burger, S. \& Tollman, S.M., 1999, 'The Dikgale field site', South African Medical Journal 89(8), 851-852.

Allen, L.H., Rosado, J., Casterline, J., Martinez, H., Lopez, P., Munoz, E. \& Black, A., 1995, 'Vitamin B-12 deficiency and malabsorption in rural Mexican communities', American Journal of Clinical Nutrition 62(5), 1013-1019.

Armitage, P., Berry G. \& Matthews J.N.S., 2002, Statistical methods in medical research, Blackwell Publishing, Massachusett.

Bogen, D.L., Duggan, A.K., Dover, G.J. \& Wilson, M.H., 2000, 'Screening for iron deficiency anaemia by dietary history in a high-risk population', Pediatrics 105(6), 1254-1259. http://dx.doi.org/10.1542/peds.105.6.1254

Cornet, M., Le Hesran, J.Y., Fievet, N., Cot, M., Personne, P., Gounoue, R., Beyeme, M. \& Deloron, P., 1998, 'Prevalence of and risk factors for anaemia in young children in southern Cameroon', American Journal of Tropical Medicine and Hygiene 58(5), 606-611.

Dannhauser, A., Bester, C.J., Joubert, G., Badenhorst, P., Slabber, M., Badenhorst, A et al., 2000, 'Nutritional status of preschool children in informal settlement areas near Bloemfontein, South Africa', Public
dx.doi.org/10.1017/S1368980000000343

De Benoist, B., McLean, E., Egli, I. \& Cogswell, M., 2008, Worldwide prevalence of anaemia 1993-2005: WHO global database on anaemia, WHO, Geneva.

Emond, A.M., Hawkins, N., Pennock, C. \& Golding, J., 1996, 'Haemoglobin and ferritin concentrations in infants at 8 months of age', Archives of Disease in Childhood 74(1), 36-39. http://dx.doi.org/10.1136/adc.74.1.36

Faber, M. \& Benade, A.J., 1999, 'Nutritional status and dietary practices of 4-24-monthold children from a rural South African community', Public Health Nutrition 2(2), 179-185. http://dx.doi.org/10.1017/S1368980099000233

Ferguson, E.L., Gibson, R.S., Opare-Obisaw, C., Ounpuu, S., Thompson, L.U. \& Lehrfeld, J., 1993, 'The zinc nutriture of preschool children living in two African countries', Journal of Nutrition 123(9), 1487-1496.

Giebel, H.N., Suleymanova, D. \& Evans, G.M., 1998, 'Anemia in young children of the Muynak district of Karakal Pakistan: Prevalence, type and correlates', American Journal of Public Health 88(5), 805-807. http://dx.doi.org/10.2105/AJPH.88.5.805
Grantham-Mcgregor, S. \& Ani, C., 2001, 'A review of studies on the effect of iron deficiency on cognitive development in children', Journal of Nutrition 131 (2 Suppl 2), 649S-668S.

Haas, J.D. \& Brownlie, T., 2001, 'Iron deficiency and reduced work capacity: A critical review of the research to determine causal relationship', Journal of Nutrition 1312 (2 Suppl 2), 676S-690S

Hassan, K., Sullivan, K.M., Yip, R. \& Woodruff, B.A., 1997, 'Factors associated with anaemia in refugee children', Journal of Nutrition 127 (11), 2194-2198.

Kapur, D., Agarwal, K.N., Sharma, S., Kela, K. \& Kaur, I., 2002, 'Iron status of children aged 9-36 months in an urban slum integrated child development services project in Delhi', Indian Pediatrics 39, 136-144.

Kilbride, J., Baker, T.G., Parapia, L.A. \& Khoury, S.A., 2000, 'Incidence of irondeficiency anaemia in infants in a prospective study in Jordan', European Journal of Haematology 64(4), 231-236. http://dx.doi.org/10.1034/j.16000609.2000.90037.x

Kirsten, G.F., Heese, H.D., De Villers, S., Dempster, W.S., Varkevisser, H.E.\& Hoffman, M., 1984, 'The prevalence of iron deficiency in apparently healthy Cape Coloured infants', South African Medical Journal 65(10), 378-380.

Labadarios, D. \& Van MiddelKoop, A., 1995, 'Children aged 6-71 months in South Africa, 1994: Their anthropometric, vitamin A, iron and immunisation coverage status', The South African Vitamin A Consultative Group (SAVACG) Isando, Johannesburg.

Ladzani, R., Steyn, N.P. \& Nel, J.H., 1998, 'Infant feeding practices of Pedi women in six semi-rural areas of Northern Province', South African Journal of Epidemiology six semi-rural areas of Norther
and Infection 13(2), 63-65.

Lartey, A., Manu, A., Brown, K.H. \& Dewey, K.G., 2000, 'Predictors of micronutrient status among six- to twelve-month old breastfed Ghanaian infants', Journal of

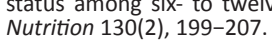

Lawson, M.S., Thomas, M. \& Hardiman, A., 1998, 'Iron status of Asian children aged 2 years living in England', Archives of Disease in Childhood 78(5), 420-426. http:// dx.doi.org/10.1136/adc.78.5.420

Male, C., Persson, L.A., Freeman, V., Guerra, A., Van't Hof, M.A., Haschke, F. \& Euro-Growth Iron Study Group, 2001, 'Prevalence of iron deficiency in 12-moold infants from 11 European areas and influence of dietary factors on iron status (Euro-Growth-Study)', Acta Paediatria 90(5), 492-498. http://dx.doi. org/10.1080/080352501750197601

Malope, B.I., MacPhail, A.P., Alberts, M. \& Hiss, D.C., 2001, 'The ratio of serum transferrin receptor and serum ferritin in the diagnosis of iron status', British Journal of Haematology 115(1), 84-89. http://dx.doi.org/10.1046/j.13652141.2001.03063.x

Mamabolo, R.L., Alberts, M., Steyn, N.P., Delemarre-van de Waal, H.A., Nthangeni, N.G. \& Levitt, N.S., 2004a, 'Evaluation of the effectiveness of iron and folate supplementation during pregnancy in a rural area of Limpopo province', South African Journal of Clinical Nutrition 17(1), 15-21.

Mamabolo, R.L., Alberts, M., Mbenyane, G.X., Steyn, N.P., Nthangeni, N.G., Delemarrevan de Waal, H.A. et al., 2004b, 'Feeding practices and growth of infants from birth to 12 months in the central region of the Limpopo Province of South Africa', Nutrition 20(3), 327-333.

Mamabolo, R.L., Alberts, M., Steyn, N.P. \& Levitt, N.S., 2006, 'Can the high prevalence of micronutrient deficiency, stunting, overweight and stunting and overweight be explained by diet?', South African Journal of Clinical Nutrition 19(3), 102-113. http://dx.doi.org/10.1016/j.nut.2003.11.011

Mostert, D., 2000, 'A longitudinal study to determine the dietary intake and nutritional status of pregnant women in Dikgale, their breastfeeding and weaning practices and the nutritional status of their infants', Masters dissertation, Dept. of Nutrition, University of the North, South Africa.

Muhe, L., Oljira, B., Degefu, H., Jaffar, S. \& Weber, M.W., 2000, 'Evaluation of clinica pallor in the identification and treatment of children with moderate and severe anaemia', Tropical Medicine and International Health 5(11), 805-810. http:// dx.doi.org/10.1046/j.1365-3156.2000.00637.x

National Food Fortification Task Group 1998, South Africa Department of Health, Pretoria.

National Food Fortification Task Group 2002, South Africa Department of Health, Pretoria.

Neumann, C.G. \& Harrison, G.G., 1994, 'Onset and evolution of stunting in infants and children. Examples from the human nutrition collaborative research support program, Kenya and Egypt studies', European Journal of Clinical Nutrition 48 program, Kenya and
(Suppl 1), S90-S102.

Oelofse, A., Van Raaij, J.M., Benade, A.J., Dhansay, M.A., Tolboom, J.J. \& Hautvast, J.G. 2002, 'Disadvantaged black and coloured infants in two urban communities in the Western Cape, South Africa differ in Micronutrient status', Public Health Nutrition 5(2), 289-294. http://dx.doi.org/10.1079/PHN2002263

Oski, F., 1993, 'Iron deficiency in infancy and childhood', New England Journal of Medicine 329(3), 190-193. http://dx.doi.org/10.1056/NEJM199307153290308

Rogers, L.M., Boy, E., Miller, J.W., Green, R., Rodriguez, M. \& Allen, L.H., 2003, 'Predictors of cobalamin deficiency in Guatemalan school children: Diet, Helicobacter pylori, or bacterial overgrowth?', Journal of Pediatric Gastroenterology and Nutrition 36(1), 27-36. http://dx.doi.org/10.1097/00005176-200301000-00008

Schellenberg, D., Schellenberg, J.R., Mushi, A., Savigny, D., Mgalula, L., Mbuya, C. \& Victora, C. G., 2003, 'The silent burden of anaemia in Tanzanian children: A community-based study', Bulletin of the World Health Organization 81(8), 581-590.

Sherriff, A., Emond, A., Hawkins, N. \& Golding, J., 1999, 'Haemoglobin and ferritin concentrations in children aged 12 and 18 months', Archives of Disease in Childhood 80(2), 153-157. http://dx.doi.org/10.1136/adc.80.2.153 
Specker, B.L., Black, A., Allen, L.H. \& Morrow, F., 1990, 'Vitamin B-12: Low milk concentrations are related to low serum concentrations in vegetarian women and to methylmalonic aciduria in their infants', American Journal of Clinical Nutrition 52(6), 1073-1076.

Specker, B.L., Miller, D., Norman, E.J., Greene, H. \& Hayes, K.C., 1988, 'Increased urinary methylmalonic acid excretion in breast-fed infants of vegetarian mothers and identification of an acceptable source of vitamin B12', American Journal of Clinical Nutrition 47(1), 89-92.

SPSS Inc., 2013, SPSS for windows base system user's guide, Release 22.0, SPSS Inc. Chicago.

Steyn, N.P., Badenhorst, C.J., Nel, J.H. \& Jooste P., 1992, 'The nutritional status of Pedi preschool children in two rural areas of Lebowa', South African Journal of Food Science and Nutrition 4(2), 24-28.

Steyn, N.P., Badenhorst, C.J., Nel, J.H. \& Ladzani, R., 1993, 'Breast-feeding and weaning practices of Pedi mothers and the dietary intakes of their preschool children', practices of Pedi mothers and the dienal of Food Science and Nutrition 5(1), 10-15.
South

Steyn, N.P., Monyeki, K.D., Alberts, M., Nthangeni, N.G. \& Burger, S., 2001, 'Seasonal variation in dietary intake of the adult population of Dikgale', South African Journal of Clinical Nutrition 14(4), 143-145.

Stoltzfus, R.J., Chwaya, H.M., Montresor, A., Albonico, M., Savioli, L. \& Tielsch, J.M., 2000 , 'Malaria, hookworm and recent fever are related to anaemia and iron status indicators in 0-to 5-y old Zanzibari children and these relationships change with age', Journal of Nutrition 130(7), 1724-1733.
Thane, C.W., Walsmsley, C.M., Bates, C.J., Prentice, A. \& Cole, T.J., 2000, 'Risk factors for poor iron status in British toddlers: Further analysis of data from the National Diet and Nutrition Survey of children aged 1.5-4.5 years', Public Health Nutrition 3(4), 433-440. http://dx.doi.org/10.1017/S1368980000000501

UNICEF/WHO 1999, Prevention and control of iron deficiency anaemia in women and children, Report of the UNICEF/WHO regional consultation GENEVA, Switzerland.

United Nations, ACC/ SCN, 1991, Controlling iron deficiency. Nutrition policy discussion, United Nations, Paper 9, New York.

Verhoef, H., West, C.E., Ndeto, P., Burema, J., Beguin, Y. \& Kok, F.J., 2001, 'Serum transferrin receptor concentration indicates increased erythropoiesis in Kenyan children with asymptomatic malaria', American Journal of Clinical Nutrition 74(6) 767-775.

Wharf, S.G., Fox, T.E., Fairweather-Tait, S.J. \& Cook, J.D., 1997, 'Factors affecting iron stores in infants 4-18 mo. of age', European Journal of Clinical Nutrition 51(8), 504-509. http://dx.doi.org/10.1038/sj.ejcn.1600428

WHO, 2012, 'Serum and red blood cell folate concentrations for assessing folate status in populations', Vitamin and Mineral Nutrition Information System, World Health Organization, Geneva, Switzerland.

WHO/CDC, 2008, 'Assessing the iron status of populations: including literature reviews: report of a Joint World Health Organization/Centers for Disease Control and Prevention Technical Consultation on the Assessment of Iron Status at the Population Level', Geneva, Switzerland, 06-08 April 2004, 2nd ed. 